\title{
Changes in Hematological and Serum Biochemical Values of Emus (Dromaius novaehollandiae) Affected with Leg Deformities
}

\author{
L.S.S. Vara Prasad Reddy ${ }^{1 *}$, B.R. Naik ${ }^{1}$, B. Sudhakara Reddy ${ }^{2}$, \\ S. Sivajothi ${ }^{3}$ and M. Haritha ${ }^{4}$
}

${ }^{1}$ Department of Veterinary Physiology, ${ }^{2}$ Departmnet of Clinical Complex (Veterinary Medicine), ${ }^{3}$ Department of Veterinary Parasitology, College of Veterinary Science, Proddatur-516360, Sri Venkateswara Veterinary University, Tirupati, Andhra Pradesh, India

${ }^{4}$ Department of Biochemistry, Tirupati, Andhra Pradesh, India

*Corresponding author

\section{A B S T R A C T}

\section{Key words \\ Emu, Calcium, Hematology, Leg deformities \\ Article Info \\ Accepted: \\ 06 August 2018 \\ Available Online: \\ 10 September 2018}

The aim of the present study is to estimate the haematological and serum biochemical values and to study the role of calcium in emus affected with leg deformities. Investigations were carried out on ten adult emu birds affected with leg deformities at private emu farm, Proddatur, Y.S.R Kadapa District, Andhra Pradesh, India. The haematological parameters viz., total erythrocyte count, total leukocyte count, haemoglobin, packed cell volume and erythrocyte sedimentation rate were measured, while the serum biochemical values like total protein, calcium, phosphorous, creatinine, cholesterol, glucose, urea, uric acid, alanine amino transferase and aspartate amino transferase were estimated. There is a significant increase in total white blood corpuscles, erythrocyte sedimentation rate, total protein, glucose, uric acid and creatinine and significant decrease in calcium levels in affected emus.

\section{Introduction}

The emus (Dromaius novaehollandiae) belong to ratite group and the second largest bird by the height in the world, after the ostrich. Emu farming in India is gaining commercial importance (Saivinay et al., 2018), and emu products have attracted attention as alternate medical drugs (Abimosleh et al., 2012; Jeengar et al., 2015). Hence, many poultry farmers have diversified from poultry to emu farming because of its economic value. Leg deformities are a common problem in emu chicks reared under captive condition (Mehala et al., 2015), leg deformities such as tibiotarsal rotation, slipped tendon, twisted or rolled toes, Osteomalacia and Rickets have been commonly observed. Tibiotarsal rotation is characterized by deformity of the coxofemoral joint due to rotation of the tibiotarsal bone above the hock joint leading to turning of the foot to the outside (Hahulski et al., 1999). 
Blood profiling is a helpful tool in detecting the metabolic diseases, nutritional deficiencies, antioxidant enzyme status, screening of health status, and welfare of animals and blood exams are an indispensable tool in bird medicine (Varaprasad Reddy et al., 2009). Comprehensive health assessments on wild bird productions, as haemotology, can be used to assess the effects of many health related problems (Gallo et al., 2015), such as contaminant intoxication, malnutrition and exposure to infection. There is very little information available on the haematological and serum biochemical values of emus affected with leg deformities, tibio tarsal rotation etc. Hence, the objectives of current study was to estimate the haematological and serum biochemical values in both healthy emus and emus affected with leg deformities and to study the role of these values in affected emus.

\section{Materials and Methods}

The present study was carried out on ten emu birds of 6-10 months age group. The birds were raised under semi-intensive system in an Emu farm located at Proddatur, Y.S.R Kadapa District of Andhra Pradesh with a night shelter and free access to outdoor space. They were fed a balanced formulated diet. Drinking water was provided Ad libitum.

Blood samples were collected from 10 affected birds and 10 healthy birds as control. Sample collection was carried out aseptically by using 21 gauge needles. The Jugular Vein is preferred site for collection of blood from Emus, especially on the right side (Reddy et al., 2003). Blood samples were collected into serum separator tubes, and the serum obtained from the tubes was frozen and stored for subsequent use in estimation of Serum biochemical values. The serum biochemical values like total protein, calcium, phosphorous, creatinine, cholesterol, glucose, urea, uric acid, alanine amino transferase (ALT) and aspartate amino transferase (AST) were estimated. Whole blood was collected for estimation of total erythrocyte count (TEC), total leukocyte count (TLC), hemoglobin $(\mathrm{Hb})$, packed cell volume (PCV), erythrocyte sedimentation rate (ESR). The blood was analyzed for hematology parameters like TEC, TLC by Neubauer's Hemocytometer method, $\mathrm{Hb}$ by Sahli's haemoglobinometer method, PCV by microhematocrit method, ESR by Wintrobes method by following procedure given in standard methods as described by Schalm et al., 1975. Peripheral blood smears was collected to screen for haemoprotozoans and faecal samples were collected to screen for enteric parasitic ova (Sivajothi and Reddy, 2018). Statistical analysis of the data was analyzed by one student t-test as per Snedecor and Cochran (1994).

\section{Results and Discussion}

Mean hematological values of emus affected with leg deformities and healthy emus are presented in Table 1 . In this study the mean total white blood corpuscles count was significantly $(\mathrm{p}<0.05)$ higher in emus affected with leg deformities than healthy emus. The significant increase in total white blood corpuscles in affected emus could be due to leucocytosis and or mobilization of leucocytes into the general circulation which is triggered by stress and physical disturbances caused by leg deformities.

Total red blood corpuscles, Hemoglobin and PCV values were slightly increased in emus affected with leg deformities but, there was no significant difference in these parameters in both healthy and affected emus. The slight increase in PCV values of affected emus in present study may be due to dehydration as a result of reduction of feed and water intake by the leg deformities affected birds. Severely 
affected birds cannot stand and thus injure the hock joint while attempting to stand up. Consequently, affected birds find difficulty to reach food and water troughs and eventually die of starvation or dehydration (Gilslider, 1994). Femoral and tibiotarsal fractures frequently results in severe haemorrhages followed by hypovolemic shock and death (Charuta et al., 2010; Bello et al., 2017). Similarly, Menon et al., (2013) also reported elevated PCV values in dehydrated emu birds. The ESR values in this study were significantly $(p<0.05)$ higher in emus affected with leg deformities than healthy emus.

Mean serum biochemical values of healthy and affected emus were presented in Table 2. Total Protein, glucose, uric acid and creatinine values in emus affected with leg deformities were significantly $(\mathrm{p}<0.05)$ higher than healthy emus. But, the calcium levels in affected emus were significantly $(\mathrm{p}<0.05)$ lower than healthy emus. Mean cholesterol, urea, phosphorus, ALT and AST values do not differ significantly in healthy and affected emus. The increase in total protein in emus affected with leg deformities than healthy emus is in agreement with the findings of Charles Noriega (2000) who reported high protein values in birds during severe inflammation. Total serum protein increases when the protein intake exceeds the requirement for growth and maintenance.

A high protein diet is often fed to commercial ratites in order to achieve fast weight gain (Deeming et al., 1993). This high protein diet together with the lack of proper exercise increases the incidence of leg deformity in captive ratites (Mehala et al., 2015) (Fig. 1).

Table.1 Mean hematological parameters in emu birds affected with leg deformities

\begin{tabular}{|l|l|l|}
\hline \multicolumn{1}{|c|}{ Parameter } & \multicolumn{1}{|c|}{ Healthy emus } & \multicolumn{1}{|c|}{ Affected emus } \\
\hline Total Red blood corpuscles $\left(\mathbf{X} 10^{6} / \mathrm{ul}\right)$ & $3.22^{\mathrm{a}} \pm 0.03$ & $3.34^{\mathrm{a}} \pm 0.02$ \\
\hline Total White blood corpuscles $\left(\mathbf{X} 10^{3} / \mathrm{ul}\right)$ & $12.14^{\mathrm{a}} \pm 0.11$ & $13.37^{\mathrm{b}} \pm 0.24$ \\
\hline Haemoglobin (g/dl) & $14.21^{\mathrm{a}} \pm 0.13$ & $14.26^{\mathrm{a}} \pm 0.14$ \\
\hline Packed Cell Volume (\%) & $38.14^{\mathrm{a}} \pm 0.19$ & $38.28^{\mathrm{a}} \pm 0.21$ \\
\hline Erythrocyte Sedimentation Rate $(\mathrm{mm} / \mathrm{hr})$ & $7.19^{\mathrm{a}} \pm 0.04$ & $8.84^{\mathrm{b}} \pm 0.05$ \\
\hline
\end{tabular}

Values in the same row bearing different superscripts differ significantly $(\mathrm{P}<0.05)$.

Table.2 Mean serum biochemical parameters in emu birds affected with leg deformities

\begin{tabular}{|l|l|l|}
\multicolumn{1}{|c|}{ Parameter } & \multicolumn{1}{c|}{ Healthy emus } & \multicolumn{1}{c|}{ Affected emus } \\
\hline Total Protein (g/dl) & $4.82^{\mathrm{a}} \pm 0.27$ & $5.14^{\mathrm{b}} \pm 0.54$ \\
\hline Glucose (mg/dl) & $148.2^{\mathrm{a}} \pm 11.4$ & $158.7^{\mathrm{b}} \pm 10.62$ \\
\hline Cholesterol (mg/dl) & $120.33^{\mathrm{a}} \pm 7.6$ & $120.42^{\mathrm{a}} \pm 8.4$ \\
\hline Urea (mg/dl) & $8.24^{\mathrm{a}} \pm 1.5$ & $8.44^{\mathrm{a}} \pm 1.3$ \\
\hline Uric acid (mg/dl) & $11.45^{\mathrm{a}} \pm 1.4$ & $13.17^{\mathrm{b}} \pm 1.2$ \\
\hline Creatinine (mg/dl) & $0.12^{\mathrm{a}} \pm 0.03$ & $0.24^{\mathrm{b}} \pm 0.06$ \\
\hline Calcium (mg/dl) & $12.72^{\mathrm{a}} \pm 1.8$ & $10.68^{\mathrm{b}} \pm 1.5$ \\
\hline Phosphorus (mg/dl) & $4.12^{\mathrm{a}} \pm 0.8$ & $3.96^{\mathrm{a}} \pm 0.5$ \\
\hline ALT (IU/L) & $38.45^{\mathrm{a}} \pm 2.4$ & $39.45^{\mathrm{a}} \pm 1.4$ \\
\hline AST (IU/L) & $121.25^{\mathrm{a}} \pm 11.8$ & $121.45^{\mathrm{a}} \pm 12.4$ \\
\hline
\end{tabular}

Values in the same row bearing different superscripts differ significantly $(\mathrm{P}<0.05)$. 
Fig.1 Leg deformities in Emu bird

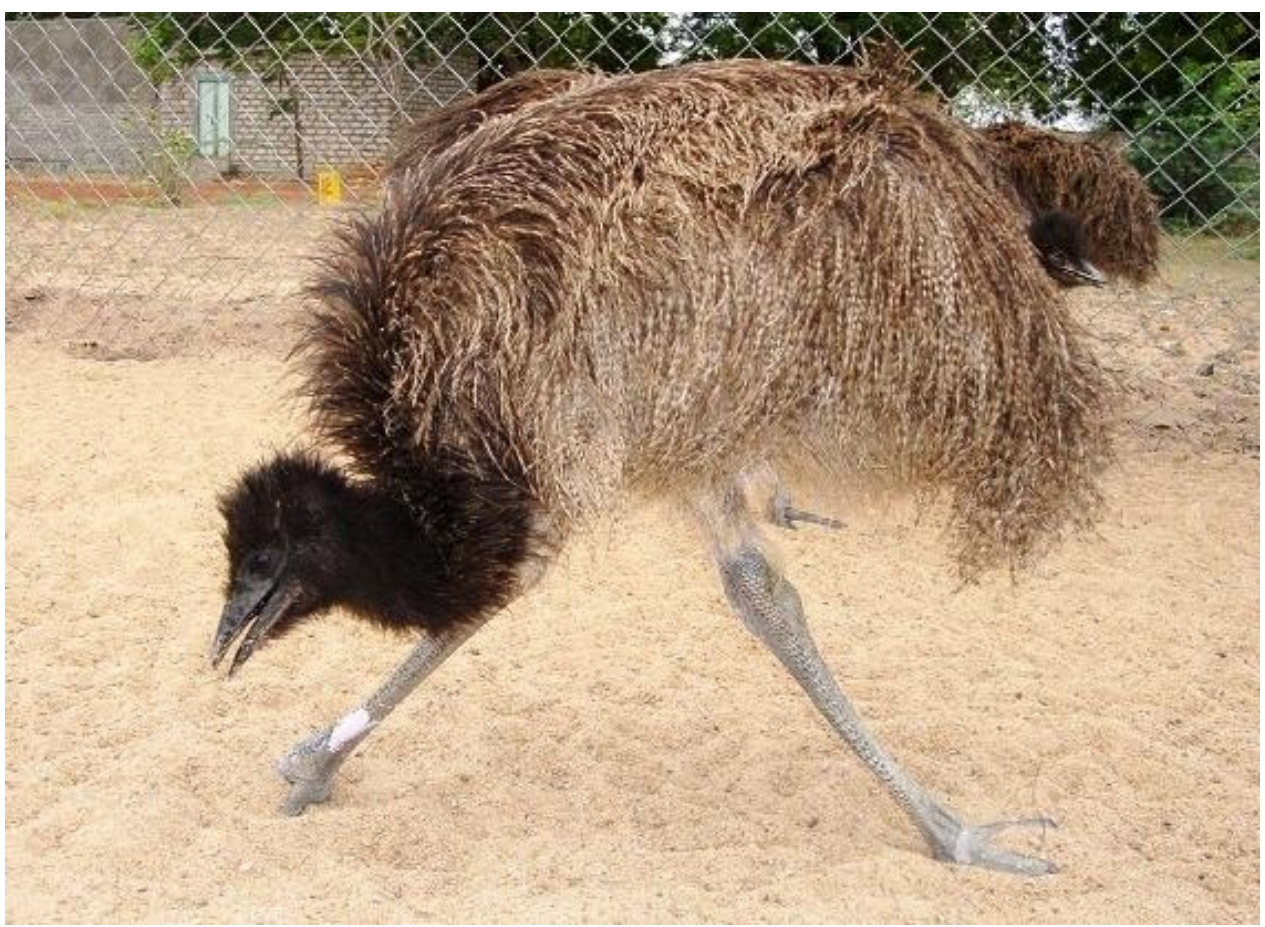

In the present study there was a significant increase in serum Glucose values in emus affected with leg deformities than healthy emus. Such elevation in glucose levels was possible as a result of stress and due to release of glucocorticoids in affected birds. This increase in glucose levels were in agreement with the findings of Siegel (1995) who reported high glucose values in birds during handling stress.

There was a significant increase in uric acid and creatinine values in the present study in emus affected with leg deformities than healthy emus. Despite these differences, mean uric acid values remained within normal limits in both healthy and affected emus, according to Campbell (2004), uric acid levels in serum below $15 \mathrm{mg} / \mathrm{dl}$ are normal. Uric acid, the major end product of protein metabolism in birds, and its levels can be used to detect dehydration and renal diseases as Uric acid levels can be highly increased in dehydration in birds (Hochleithner, 1994).
The higher Uric acid levels possibly reflect the protein levels in the diet.

In the present study there was a significant decrease in serum Calcium levels in emus affected with leg deformities than healthy emus was in agreement with the finds of Bezuidenhout et al., (1994), who also observed lower calcium levels in birds with leg deformities than healthy birds. Aganga $e t$ al., (2003) was reported limb deformities and affected bone structures in birds with low calcium levels. Wyss et al., (2010) reported that calcium deficiencies along with manganese and copper are the potential causes of leg deformities in Ostriches. Some deficiencies in vitamins and minerals are reported to cause leg deformities and slipped tendons in birds especially Vitamin D3, biotin, choline, niacin, folic acid, pyridoxine, calcium, manganese and zinc (Kistner and Reiner, 2002 ; Aganga et al., 2003). In addition to these deficiencies some other factors like food deprivation, a high amino 
acid to protein feed ratio, a low dietary calcium level, a high energy feed had been linked to tibiotarsal rotation in birds reported by Hahulski et al., (1999). Genetics, nutrition, excessive growth rates due to over feeding with high protein diet and inadequate exercise are also likely to be involved in leg deformities of ratites (Reece and Buttler, 1984; Bruning and Dolensenk, 1986).

Serum hematological findings and biochemical values in emu birds were determined in both healthy and emus affected with leg deformities. The findings from our study showed that levels of total white blood corpuscles, ESR, total protein, glucose, uric acid and creatinine are significantly higher in leg deformities affected emus than healthy emus. But, calcium levels in affected emus are significantly lower than healthy emus. These results clearly indicate that deficiency of calcium even with higher total protein content leads to leg deformities in emus. It is concluded that the leg deformities of the emus seem to be a multifactorial problem. Calcium deficiency can be a potential cause but also the elevated total protein levels are an additional factor in leg deformity problem in emu birds.

\section{Acknowledgement}

The authors are thankful to the authorities of Sri Venkateswara Veterinary University for providing the facilities to carry out the research work.

\section{References}

Abimosleh, S.M., Tran, C.D. and Howarth, G.S. 2012. Emu Oil: A novel therapeutic for disorders of the gastrointestinal tract? Journal of Gastroenterology and Hepatology. 27(5): 857-861.

Aganga, A.A., Aganga, A.O and Omphile U.J. 2003. Ostrich Feeding and Nutrition. Pakistan Journal of Nutrition. 2: $60-67$.
Bello, A., Frei, S., Peters, M., BalkemaBuschmann, A., Baumga rtner, W. and Wohlsein, P. 2017. Spontaneous diseases in captive ratites (Struthio niformes) in northwestern Germany: A retrospective study. PLoS ONE 12(4): e0173873.

Bezuidenhout, A.J., Burger, W.P, Reyers, F and Soley, J.T. 1994. Serum and bone-mineral status of ostriches with tibiotarsal rotation. Onderstepoort Journal of Veterinary Research 61 (3): 203 - 206.

Bruning, D.F. and Dolensenk, E.P. 1986. Ratites in M.E. Fowler (ed.), Zoo and Wild Animal Medicine. Philadelphia: WB Saunder, $165-180$.

Campbell, T.W. 2004. Clinical chemistry of birds. In: Thrall MA, editor. Veterinary hematology and clinical chemistry. Philadelphia, PA: Lippincott Williams \& Wilkins; p. 479-492.

Charles Noriega, M.L.V.C. 2000. Apuntes de hematología aviar: material didático para curso de hematologia aviária. México: Departamento de Produccíon Animal: Aves, Universidad Nacional Autónoma de México. 70 p. Apostila mimeo.

Charuta, A., Dzierzecka, M. and Cooper, R.G. 2010. The content of selected minerals in the tibio-tarsal bone in 14-month-old ostriches (Struthio camelus) as influenced by sex and place of the bone. Vet Med Zoot. 52(74): 8-12.

Deeming, D.C., Ayres, L. and Ayres, F.J. 1993. Observations on the commercial production of Ostrich (Struthio camelus) in the United Kingdom: Rearing of chicks. Veterinary Record. 132: 627-631.

Gallo, S.S.M., Ederli, N.B., Boa-Morte, M.O. and Oliveira, F.C.R. 2015. Hematological, morphological and morphometric characteristics of blood cells from rhea, Rhea Americana (Struthio niformes: Rheidae): a standard for Brazilian birds. Brazilian Journal of Biology. 75(4): 953-962. http://dx.doi. org/10.1590/1519-6984.03414.

Gilslider, E. 1994. Ratite Orthopedics. In: Redig, P. T. and Fudge, A. M. (eds.). Avian Orthopedics, Seminars in Avian 
and Exotic Pet Medicine. W.B. Saunders, Philadelphia.

Hahulski, G., Marcellin-Little, D.J. and Stoskopf, M.K. 1999. Morphologic evaluation of rotated tibiotarsal bones in immature ostriches (Struthio camelus). Journal of Avian Medicine and Surgery. 13(4): 252-260.

Hochleithner, M. 1994. Biochemistries. Pages 223-245 in Avian Medicine. B.W. Ritchie, G.J. Harrison, and L.R. Harrison, ed. Wingers Publishing Inc., Lake Worth, FL.

Jeengar, M.K., Kumar, P.S., Thummuri, D., Shrivastava, S., Guntuku, L., Sistla, R. and Naidu, V.G.M. 2015. Review on emu products for use as complementary and alternative medicine. Nutrition. 31(1): 2127.

Kistner, C.H. and Reiner, G. 2002. Strausse: Zucht, Haltung und Vermarktung. Stuttgart: Eugen Ulmer GmbH and Co. 71 -83 .

Mehala, C., Jagatheesan, P.N.R., Kumar, P.S., Paramasivam, A and Henry, A.C.E. 2015. Incidence of tibiotarsal rotation and its effect on production performance in emu birds. 92(10): $44-45$.

Menon, D.G., Bennett, D.C., Schaefer, A.M.and Cheng, K.M. 2013. Hematological and serum biochemical profile of farm emus (Dromaius novaehollandiae) at the onset of their breeding season. Poultry Science 92: 935-944.

Reddy Y R., Viroji Rao, S.T., Veerabrahmaiah, K. Satish kumar, K. and Shakila, S. 2003. Haematological parameters of Emu, Indian Veterinary Journal. 80:1308-1309.

Reece, R. and Buttler, R. 1984. Some observations of the development of long bones of ratite birds. Australian Veterinary Journal. 61: $403-405$.

Saivinay, B., Harika, Ch., Naik, B.R., Sivakumar, A.V.N., Varaprasad Reddy, L.S.S. and Harimallikarjuna Reddy, B. 2018. Seasonal changes effecting the growth performance of Emu birds reared under Intensive farming system. International Journal of Current Microbiology and Applied Sciences, 7(6):1780-1785.

Schalm, O.W., Jain, N.C., and Carrot, F.J. 1975: Veterinary haematology, $3^{\text {rd }} \mathrm{edn}$, Lee and Febiger, Philadphia.

Siegel, H.S. 1995. Stress, strains, and resistance. British Poultry Science. 36: 322.

Sivajothi, S. and Reddy, B.S. 2018. Cryptosporidiosis in Pet Birds - Zoonotic Alert to Kids. Int J Avian \& Wildlife Biol 3(2): 00051 DOI: 10.15406/ijawb.2018.03.00051

Snedecor, G.W. and E.G. Cochran, 1994. Statistical Methods, 8th edn., Iowa State University Press, USA

Varaprasad Reddy, L.S.S., Thangavel, A. Leela, V. and Raju, K.V.S.N. 2009. Antioxidant enzyme status in Broilers: Role of dietary supplementation of Tulasi (Ocimum sanctum) and selenium. Tamilnadu Journal of Veterinary and Animal Sciences, 5(6): $251-256$.

Wyss, F., Hebel, C., Deb, A. Tugade, D., Arif, A. Dorrestein, G.M. and Hammer, S. 2010. Manganese deficiency associated leg deformities in red-necked ostriches (Struthio camelus camelus). awwp.alwabra.com/wp-content/uploads/ 2014/04/108.

\section{How to cite this article:}

Vara Prasad Reddy, L.S.S., B.R. Naik, B. Sudhakara Reddy, S. Sivajothi and Haritha, M. 2018. Changes in Hematological and Serum Biochemical Values of Emus (Dromaius novaehollandiae) Affected with Leg Deformities. Int.J.Curr.Microbiol.App.Sci. 7(09): 723-728. doi: https://doi.org/10.20546/ijcmas.2018.709.086 